\title{
LITERATURE AS REFERENCE FOR A PHILOSOPHY MAN-AND-TIME, AS GIVEN IN LATIN-AMERICA
}

W. VÁZQUEZ

Assistant Professor - Miami University, Oxford, Ohio

I. - First of all let us boldly assume that we definitely need to interpret Man-and-Time here-now from an angle that might give us a better perspective for the never ending task of answering certain questions that bother us to a point that we-all, being unable to understand them correctly, take a number of alternatives all shaded by the common will to conquer or perish, as in a casus belli.

I. - Of course, we have before us when we confront ourselves with the problem of Man-and-Time in its synchronic dimension, the tremendous disadvantage of being ourselves part and parcel of the here-now unquestionably involving and revolving us. When the diachronic dimension is analyzed we are, naturally, more "objective". We are not vivencially, so to speak, engaged with the circumstance (Ortega y Gasset). Orthodoxically speaking, the so called Social Sciences, deal with these things. And, as we know, the sociological and psychological sciences (sociology, anthropology, political science, economics, psychology) deal with the synchronic dimension and History with diachronics. Thus, it is the task of the historical studies to deal with both the here-now and the Past. Being so, sociology, anthropology, political science, economics, psychology lose the "name" of Science to get the status of historical methods proper to assemble information about the here-now. "What is in a name", one might parody Shakespeare? The thing is that in our particular case the name (Science) is so overbearing that we lose the entity named after; i. e. the Homo Socius, Homo Politicus, Homo Faber, Homo Cogitatus, and the like. (The Homo Animalis in the hands of the psychiater or psychoanalyst is a different story!) The object of study and/or observation becomes scientific as certain other 
kinds of objects such as force and matter, totally unlike the former which do not admit reification. Moreover, the division of labor proper of these disciplines has compartmentalized Man-and-Time to such an extent that Man \& Time have academically become frozen up, and consequently lost its plasticity, its dynamics, its never ending changing character. Man \& Time have become, we observe, a sort of Things in a Showcase.

III. - But a second of course is the reasoning we get from the above item. We tend to admit that this is the kind of world we live in. Well now, the concept world, here is of most interesting positive value. On this we agree. But on what we do disagree is the almost dogmatic belief that we live in a SCIENTIFIC AGE. Doubtless, today we find many, too many machines that Simplify matters enormously - comparatively speaking!

When the domestication of plants and animals we use today took place ages ago; when the wheel was first discovered (invented rather) and also the number zero was first conceptualized amongst an array of other things, the impact of those Simplifications of matter-and-force-and-concept was equally significant for Man-and-Time. But for a number of reasons, these Simplifications were far more controlled by Man than our Simplifications of today are. The domestication of, shall we say the horse, was more rationally controlled than a bomber is, be it B-52, or Mig 21 or whatever. Then, what we may advance as a mere hypothesis, is that today fewer and fewer men control the Simplifications we have at hand. And in consequence, in the good-old-days men were more engaged in the functioning of the said Simplifications. This pedal-like epoch (civilization?) was less frustrating on a whole.

IV. - From the item just discussed we may give the impression that we are advancing the naive idea that men in the old-days were more human (in the philantropic sense) than men here-now. Not so, however. Man, as the long history of civilization reminds us if we care to open an archeology book, is and perhaps will always be, a complex and contradictory psychosomatic entity, more often than not falling into regressive behavior of some sort.

V. - Therefore, as the title above implies, we may very well explore once again an angle which is not carefully explored by many of us and/or not given the attention it may deserve. Let us advance, for a moment, toward certain concrete aspects in order to get to what we mean.

a) There is a first fact that needs no demonstration; LatinAmerica is a political entity in the world today.

b) There is a second fact requiring no further exploration; Too much attention if given to (the so called social) sciences to 
solve with a higher degree of accuracy the ever mounting acute problems confronting that part of the world. trouble.

c) We need not prove that indeed, Latin-America is in

d) We may state with no expected opposition that the world in this twenthieth century has also been in trouble and still is, for that matter.

e) Now, we can borrow the concept Man and Time from Heidegger and tell both the planners (called social scientists and experts, the leaders (and why not their counterparts the declared and potential traitors?) and ourselves that we (not the we-all but the we-vorried-about-Man-and-Time (philosophers?)) as Man are experiencing the anxiety of Time as much as anybody else. But unlike anybody else, we are not going to base our discussion on so called scientific facts and biographical people but on creative situations and characters (isotypes?).

f) Is is our thinking at this time that literature in LatinAmerica is offering us an extremely rich wealth of first hand material for the very difficult task of sensing Man-and-Time in the part of the world we call Latin-America.

g) Now, being literatore a field of varied ways of assembling and presenting its material, we find appropriate for now, that the poetry, short-story and essay offer us a good source where to either get or check our stuff. The novel and the drama let us underline, are equally important but have not reached, let us equally admit, the maturity we find in the same genres in Europe and in the United States; nor do they have the same quintessential content and neat perfection we do find in the three genres mentioned above.

h) So it is enough to search in the poems, essays and shortstories to find at our disposal a wealth of content that if well taken care of, can produce amazing results.

i) Unfortunately, we are told, neither the leaders nor the scientists dealing with Man-and-Time, care to read, not to say onalyze, the productivity of the creative individuals who, by the very fact that they are artists, are a sort of common depositary of the social anguish of society. "Painting is stronger than me. It makes me do whatever it wants" (Picasso, Time 12-2-'66). On the contrary, and this we can verify, there is a social prejudice against the poet and short-story writer. Not so much so, perhaps; with the essayist. But an essay is not "science", we are reminded frowningly.

VI. - Another problem, from the point of view of an orthodox scholar, or the scholar orthodoxically minded. Such and such a paper is too narrative; such and such an argument is too theoretical. In other words, too many words! In other words "it 
is literature". As we shamefully notice in our daily professional dealings, there does exist academic prejudice and so strongly many a time, that a mere step forward toward "checking and balancing" (to borrow a Constitutional term) of our errors and achievements is unthinkable. Karl Mannheim pointed this out again and again both in Germany and later on in England.

VII. - It is our contention, nevertheless, that true interdisciplinary analyses are badly needed. And if we say interdisciplinary it is becouse in spite of much use of this term, little true interdisciplinarian analyses have seen the light of day. Adding up disciplines and putting them together as papiers collés does not make something interdisciplinarian. It is a mere collection of disciplines put together.

We believe Philosophy is the authentic interdisciplinarion discipline. That is why we dare say that what we need in order to interpret Man-and-Time as best we con, is to recognize that philosophy of history (of the Karl Mannheim type), anthropological philosophy (of the Freud plus Jung type), the philosophy of art (of the Sartre and Lucáks types) and a living logic (of the Carlos Vaz Ferreira type and perhaps Henri Léfebvre's) are of the utmost importance to help us find the way toward a Conversation (in the Heideggerian sense). Incidentally, let us confront Cowper: "Talking is not always to converse".

VIII. - Why should a Latin-American come forward in the areno of international discussion with a whole string of "choses déja vues?" "Choses déjà vues" but not enough, we may answer back. A Latin-American scholar has constantly to stress, time and again the fact that we have to digest these "Choses déjà vues" from their own circumstance (Ortega y Gasset again) which is highly problematical because of their ownmost intra-history (Unamuno) - great masses of illiterate, undernourished, Indians and Negroes in a marginal status; average life expectancy very low; average infant mortality very high; average population increase higher than food supply; reactionary élites with desproportionate military and financial means of "convincing" everybody else to come to terms with their own schemes of social utopia; etc., etc. Now this sort or forgotten history is the story we find in the poems, short-stories, essays, novels and drama of Latin-America. That is why we believe this mixing up of Freud, Jung, Mannheim, Heidegger, Sortre and so on and so forth, is the mental exercise we must endeavor to arrive at, a sort of intelligent understanding of the principia media (Mannheim) underlying the political entity we are here interested in. Also, a Latin-American scholar of the younger generation seems to many critics and scholars too fussy, too emotional, too impatient. This, on the other hand is widely noticed in their "scientifes papers". 
As everything else, this is partly true and partly false. The raison d'être of this rather impatient temperament is that for a number of ears if not a century or so, the consensus was to be more ritualist than questioner, more royalist than a king, and to follow Comte's law of linear order. There used to be a deeply sophisticated step by step procedure, however inefficient the law, the analyses, the reports, the working of the national society on a whole proved to be. An enormous amount of time was lost, wasted rather. Today the totalistic, chessboard sort of thing the world came to be, is putting pressure on every one: intellectuals, leaders, workers, students, housewives, etc.

No wonder today more than ever before a whole generation of men and women seem to feel Jorge Manrique's (1440-1479) famous verses at heart with an interpretation of their own:

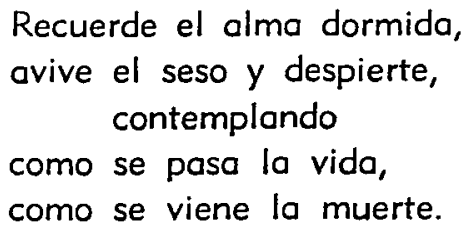

Precisely, this waking up, this brightening of the brains, this horrifying contemplation of how life slips away and death comes by, are part of the ferment producing a kind of impatience we seem to undervalue, or ignore, or misunderstand, or the three things simultaneously.

IX. - We need not here elaborate further the fact that when we refer to the Man-and-Time concept, the dialectical process proper of the two elements isolated (Man plus Time) just for the purpose of setting ourselves to work on what we mean, is understood. Therefore we will not operate with only the Social Man or vice versa the He-Man but with the two, in constant action and reaction.

$X$. Within the range and scope of this paper we shall only deal with a few examples in order to close this discussion rather than to present a sample of representative items. We must bear in mind that to attempt even the briefest sample which could be representative is a task that requires a good deal of time and attention. Even if we take up just one genre, shall we say poetry, the different schools of thought should be taken into consideration, as well as the subject matters, authors, regions and so on. 


\section{ASPIRATION}

(by Mario de Andrade 1893-1945/Braxil)

Tr. John Nist

The sweetness of poverty like this...

To lose everything yours, even the egoism of being,

So poor that you can only belong to the crowd...

I gave away everything mine, I spent all my being,

And I possess only what in me is common to all...

The sweetness of poverty like this...

I am not lonely any more, I am dissolved among equal men!

I have walked. Along my way

The emphatic mark of my steps

Remained on ground wet with morning dew.

Then the Sun oscended, heat vibrated in the air

In golden particles of light and warm breath.

The ground burned and hardened.

The mark of my feet is now invisible...

But the Earth remains, the tenderly dumb Earth,

And growing, grieving, dying in Earth,

The always equal men remain...

And 1 feel larger, equalizing myself to the equal men!...

2. -

THE RIVER AND THE SERPENT

(by Jorge de Lima 1893-1953/Brazil)

Tr. John Nist

The river and the serpent ore mysterious, my son.

On the top of that mountain

Were two circles of the Eternal.

One circle was the serpent,

The other circle was the river:

Both precipitated,

Both came searching for man,

One to purify him,

The other to poison him.

Down there they both found

The simple mon.

One offered him the Fish to feed him,

The other offered him the fruit to intoxicate him.

The river and the serpent are mysterious, my son. 
From the clouds they precipitated,

Both are crawling on the earth

Like the two ways of man,

For him to choose as his guide.

The river and the serpent are mysterious, my son:

They come from the beginning of things,

They run towards the end of everything,

And sometimes in the water of the river

You will find the black serpent.

Things were simple, my son,

But they became confused:

The river that washes you

Can also drown you,

For under the appearance of the river

Slides the serpent.

The river and the serpent are mysterious, my son:

In the beginning they were two circles,

From there they came uncoiled.

\section{(by Carlos Pezoa Véliz 1879-1908/Chile)}

Tr. G. Dundas Craig

He was a luckless devil who used to come Around the big town where I had my home;

Young, reddish, weakly, dirty and ill clad,

Forever shamefaced... Another gone to the bad!

One winter day some hunters found him dead In a little creek that near my garden led,

As, singing, with their hounds they tramped olong...

The papers that he had they searched among,

But nothing found... The local judges made Inquiry of the $n$ ight watchmon, but he said

That he knew not a thing of the deceased;

And Pérez and Pinto, neigbors, not the least.

A young girl said he might have been insane, Some wandering wastrel seeking food in vain; A man who heard their chatter saw a joke And tried to laugh... Well, they were simple folk!

Over the dead man's corpse the sexton let

A few clods fall; then rolled a cigarette,

Pulled down his broad-brimmed hat, and went his way...

After the clods, no one had aught to say!... 
Of native, savage America I sing:

My lyre has a soul, my song a lofty aim.

Not like a hammock do my verses swing,

Slung from a tropic branch, with movement tame.

As Inco, I render to the Sun, my king,

Due homage, and his powerful scepter claim;

When forth, as Spaniard, colonial times I bring,

My lines like crystal trumpets seem to flame.

My fancy tokes its form from Moorich mould:

The Andes are of silver, León of gold;

And these two have I fused with epic clamor.

The blood is Spanish, Incan its pulsation;

And were I not a Poet by vocation,

l'd wear the white Corsair's or red Chief's glamour.

5. -

MARTIN FIERRO (fragment)

(by José Hernándex 1834-1886/Argentino)

Tr. Walter Owen)

Like a hunted fox the gaucho lives,

That has got himself into a scrape,

Till some day he's off his guard, or rash,

And the dogs are on him like a flash;

For no matter how well a man can ride,

From a fall he'll not escape.

At the peaceful hour of the afternoon,

When everything seems to doze;

When the winds lie down on the prarie's breast,

And the whole wide world seems to turn to rest;

To some swamp or brake, with his load of care,

The homeless gaucho goes.

N.B.: The philosophical content is self evident.

B. - The Short-story (fragments): 


\section{(by Eduardo Mallea 1903/Argentina)}

Tr. Harrier de Onis

Montuvio took a swallow of his beer, and it suddenly ocurred to him that he might take something home with him that evening - chicken in aspic or baked ham, both favorites ofAlicia's. For a long time he had been coming in empty-handed; he had not noticed it before, now he did. We all have a responsability for these shifts of wind that come up and gradually change, becloud our relationships. The delicate shades of courtesy are always important; a feeling we trample on or offend in another way suddenly turns into a bitter poison, a wound, a corrosive acid. Alicia's sullenness might well be owing to a series of unconscious provocotions on his part, subtle provocations, muted, subliminal, those which begin and develop insidiously, secretly, like a mortal disease.

2. ASHES FOR THE WIND

(by Hernando Téllex 1909/Colombia)

\section{Tr. Harriet de Onís}

"Who's there?" This time his wife's voice sounded nearer. And then Carmen was standing in the door that opened on the front porch, holding the baby in her arms. The man got up from the log and mechanically rubbed one of his hands on the seat of his pants. Then he took off his hat. Thick, black, matted hair sprang up as though released from confinement. It looked as though it had not seen a comb for a long time. "God morning, Señora Carmen", said the visitor. The baby was playing with his mother's throat, trying to bury his fingers in its softness. $\mathrm{He}$ was only a few months old, and he reeked of mother's milk and soiled diapers.

Juan said nothing. The man was visibly disconcerted; for a few seconds there was no sound but the silence of the coutryside, and in the midst of this silence, the ever merged, ever latent noises of nature. The valley throbbed intact under sullen morning. "But the sun is going to come out," Juan thought.

"Well, I'll be going," the visitor said, and the men said goodby. Carmen was silent, her eyes on her husband. The man put on his hat again, turned his back on them, and walked slowly to the fence gate, some ten or fifteen yards from the house, and opened it carefully, the unoiled hinges giving their customary creak despite his care. Ordinary hinges made by the local blacksmith. 
"They'd better clear out." Why? The son of Simón Arévalo and his dead wife, Laura, had tried to explain the reosons for nearly half an hour. But he had been so rattled. All this business of the authorities and politics was always complicated.

3.

\section{COYOTE 13}

\section{(by Arturo Souto Alabarce 1930/Mexico)}

\section{Tr. Harriet de Onis}

Herder Juan prayed to God or to the Devil to let him get Coyote 13. Slipping his last bullet into his rifle barrel, he turned away from the nauseating sight, leaving the coyotes behind, swaying in the wind, their reddish coots imprisoning the last gleam of twilight. But the image of them, branded on Herder Juan's memory, persisted, ineffaceable as the memories of a lonely man. He could see Coyote 13 hanging there, paws crossed, head limp, vanquished and done for. The idea pleased him and filled his mind, wiping out aches, fatigues, loneliness. The sun had aged him prematurely, and his skin was crisscrossed by innumerable lines. With his square face and animal expression, Herder Juan was a cross between a beast of the field and a hermit. His reddish beard and his sun-bleached eyebrows emerged from between the wrinkles like bristles of light. And his little eyes, the pupils contracted from years of sun-glare, were grayishblue, innocent, and yet hard and dry because the only thing reflected in them was the desert, the geometric and abstract surface of vast loneliness.

4.

\section{A MAN OF CHARACTER \\ (by Rómulo Gallegos 1884/Venezuela) \\ Tr. Joan Coyne MacLean}

The hour was nearing midnight when Martin Garcés left his companions. As usual ha had stayed in the tavern until that time, drinking wine and between drags on his Egyptian cigarette, relating his amorous exploits, which were many and varied, for it was his boast that he cut a wide swath among women, and in fact, he lived for that alone.

Two drivers of the type of cab called an "owl" in Caracas slang were stationed in the shadow of the cathedral. They offered him their services.

"How about taking you home, Marty?"

"I'm ready and waiting, Martín."

"Chums," replied the man-about-town, "tonight you couldn't even wring water out of me." 
"Cleaned out, are you? That doesn't matter."

"Yon can pay later, kid. You know -"

"No, no. I'll be running along on my own two cylinders. They're tops."

The cab-drivers laughed at the ligth retort which the young man had loaded with that quality called Caracas esprit, and one of them called after him:

"Be sure you don't lose your way."

"I won't lose it, and I wouldn't be lost if I did, chum. To me it's closer than my shadow."

He continued on his way down the street, strutting with pride in his popularity, fancying he could hear one of the cab-drivers saying to the other: "That Marty! What a character! A swell guy. He'd give you the shirt off his back."

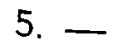

\section{THE FATHERLAND}

(by Horacio Quiroga 1873-1937/Uruguay)

Tr. Howard Young

Bees are famous for their virtues. Nevertheless, in their age-long dealings with man they have acquired notions of biology which give them some trouble when they hove to change a worker into a queen, for the do not always increase the cell space and food suply in their proper proportions. This no doubt is owing to the mental giddiness brought on by that extraordinary power they possess of changing the sex of their workers at will. Without ever neglecting the construction of their marvelous honeycombs, they nevertheless spend their life preoccupied by their superior condition and with a growing contempt for the other inhabitants of the forest, as they buzz hurriedly and officiously about the flowers.

They were the group that shouted its discovery to the forest some years after the man had gone rowing off downstream.

When the first man came to live in the forest, the anxious animals carefully observed his every act day after day.

"This is a good fellow," said the wildcat, winking an eye toward the clearing in the woods where the newcomer's shirt flashed in the sun. "I know what he is. He's a man."

"What harm can he do us?" said the clumsy, timid tapir. "He has only two legs."

"And a shotgun," growled the jaguar scornfully. "You can kill a lot of tapirs with one shotgun."

"Let's run, then," said the tapir, turning tail.

"What for?" asked the jaguar. "If he is here in the forest, he is free. He can kill us, and we also can kill him. Sometimes they have a dog. Why should we run away? Let's stay." 
"We'll stay," the rattlesnakes said meekly.

"So will we," added the other animals.

And thus beasts and man lived together in the boundless forest, all subject to assaults and bloodshed, and all in peace.

N. B. Philosophical content implied!

\section{C. - The Essay:}

1. - José Enrique Rodó (1871-1917) of Uruguay wrote an essay in which the title itself presents us with his preoccupation about Man-and-Time. In "ThePhilosophy of the Quijote and the Discovery of America" he states that the philosophy of the Quijote is the philosophy of the conquest of America. By this he means that America is the resulta of a quixotic idealism but, we may add, paradoxically Don Quixote dies without ever conquering any piece of land but the selfish and pragmatic soul of Sancho Panza. Hence Sancho Panza's transformation. Cf. Marti's idea of transforming the natural man as given in the Americas.

The topic itself is more challenging then anything else, but Rodó does show in this essay a way of searching in depth for the meaning of Continental America.

2. - Ezequiel Martínez Estrada (1895-1964) of Argentina in his essay "Carnival and Sodness" discussed a most interesting aspect of the national character (so called). "The carnival is the feast of our sadness. The psychological center is not located in the sadness, but rather in the need of gaiety".

3. - Octavio Paz (1914) of Mexico in his "The Dialectic of Solitude", touches a similar vein as his Argentinian confrère did but in a more universal sense.

4. - José Martí (1853-1895) of Cuba who, in his "Our America" presents us with a destinal ideology in a language so prodigious that it reminds us of the stories by Quiroga. His ideal of transforming the natural man into a national existencial man is a lesson in thinking into the destinal. And, incidentally, it is in this same essay that we find his famous phrase "to think is to serve", so fitting to us all, the we-worried-about-Man-and-Time.

5. - Alfonso Reyes (1889-1959) of Mexico in his essay "Capricho de America" voices with all his strength, again a destinal Latin-America that from a hopeless stage as it is now will little by little get her disjecti membra to build herself anew some day. 


\section{REFERENCES}

Spanish Stories and Tales. Edited by Harriet de Onis. The Pocket Librory. N. Y., 1956.

Modern Brazilian Poetry. An Anthology. Translated and edited, with the help of Yolanda Leite, by John Nist. Indiano University Press, 1962.

The Modernist Trend in Spanish-Americon Poetry. Translated into English verse with a Commentary by $G$. Dundas Craig. University of Californio Press, 1934. 